\title{
GAMBARAN REGULASI EMOSI REMAJA SMK KORBAN BULLYING DI SMK MULTIMEDIA TUMPANG
}

\author{
Hikmah Diajeng ${ }^{\star 1}$, Indari $^{2}$, Mustriwi $^{3}$ \\ ${ }^{1}$ Mahasiswa ITSK Rs dr. Soepraoen Malang \\ ${ }^{2,3}$ Dosen Prodi Keperawatan ITSK Rs dr. Soepraoen Malang \\ ${ }^{\star}$ Correspondence: Hikmah Diajeng \\ Email : Ajengmlg23@gmail.com
}

\begin{abstract}
ABSTRAK
Pendahuluan: Remaja yang menjadi korban bullying akan mengalami permasalahan emosional yaitu regulasi emosi, dimana remaja tidak bisa mengontrol dan mengatur emosinya. Hal ini menandakan kurangnya remaja menontrol dan mengelola emsoinya. Tujuan dari penelitian ini untuk mengetahui reguasi emosi remaja SMK korban bullying. Metode: Penelitian ini adalah penelitian deskriptif kuantitatif, dengan menggunakan total sampling. Sampel penelitian 35 responden dengan kriteria remaja SMK korban bullying Hasil: Penelitian menunjukan bahwa sebagian besar (23 remaja atau 65,5\%) mengalami regulasi emosi rendah.

Kesimpulan: Berdasarkan hasil penelitian ini diharapkan bahwa remaja diperlukan adanya pendampingan psikologis yang bisa diberikan oleh guru bimbingan konseling serta orang tua sebagai orang terdekat dari remaja diharapkan memberikan support serta motivasi kepada remaja korban bullying supaya remaja tersebut mampu mengontrol emosinya.
\end{abstract}

\section{Kata Kunci : Regulasi Emosi, Remaja SMK Korban Bullying}

\section{ABSTRACT}

Introduction: Teenagers who are victims of bullying will experience emotional problems, namely emotional regulation, where adolescents cannot control and regulate their emotions. This indicates the lack of adolescents to control and manage their emotions. The purpose of this study was to determine the emotional regulation of vocational school youth victims of bullying.

Method: This research method is descriptive, using total sampling. The research sample is 35 respondents with the criteria of being victims of bullying in SMK teenagers

Results: The results showed that most (23 adolescents or $65.5 \%)$ experienced low emotional regulation.

Conclusion: Based on these results it is expected that adolescents needed psychological assistance that can be provided by counseling teachers and parents as the closest teens are expected to provide support and motivation to the young victims of bullying so that the teenager was able to control his emotions.

Keywords: Emotion Regulation, Vocational Teenagers Victims of Bullying

\section{PENDAHULUAN}

Masa remaja merupakan masa dimana seseorang menghadapi periode baru didalam kehidupan, yaitu remaja mengalami berbagai perubahan, salah satunya adalah perubahan psikologis. Perubahan psikologis pada remaja bisa menyebabkan muncul sikap egosentrisme (Desmita, 2010). Usman (2013) menyatakan bahwa remaja bisa melakukan tindakan kekerasan dan perilaku bullying pada remaja lainnya. Remaja yang menjadi korban bullying mengalami permasalahan emosional yang kurang menyenangkan. Pada remaja korban bullying cenderung tidak bisa mengontrol dan mengatur emosinya secara sadar, 
sehingga remaja yang menjadi korban bullying mempunyai respon untuk membalas stimulus dan kadang remaja juga lebih untuk diam danmenghiraukan.

Data kasus bullying di Amerika 2018 dilaporkan oleh Josepshon Institute of Ethnics yang melakukan survei pada 43000 remaja, hasilnya $47 \%$ remaja yang berusia $15-18$ tahun telah mengalami bullying dan $50 \%$ dari remaja tersebut telah, digoda, diejek siswa lain. Di Indonesia didapatkan bahwa 10-60\%, siswa melaporkan telah menjadi korban bullying, mereka mendapatkan cemoohan, ejekan, pengucilan, pemukulan, tendangan sekurangkurangnya sekali dalam seminggu. Kasus bullying di yang terjadi sekolah menduduki peringkat teratas (KPAI 2018). KPAI mencatat dalam kurun waktu 9 tahun, dari 2011 sampai 2019, ada 37.381 pengaduan kekerasan terhadap anak.Jumlah Kasus bullying di jawa timur baik di pendidikan maupun disosial media mencapai 2.473, dan terus menunjukan peningkatan. Studi pendahuluan yang dilaksanakan di SMK Multimedia Tumpang kelas 10, pada tanggal 21 Oktober 2020, dari hasil wawancara di dapatkan bahwa 35 siswa telah menjadi korban bullying, juga dilakukan observasi selama 15 menit, menunjukan bahwa 5 remaja yang telah menjadi korban bully terlihat menyendiri, dan memisahkan diridari teman sebayanya. Menurut Zakiyah, EZ., dkk. (2017). Dampak dari remaja yang pernah dibully bisa menyebabkan terjadinnya perubahan psikologis, salah satunya adalah emosi, ketika remaja korban bullying akan muncul rasa penurunan percaya diri, depresi,hingga bunuh diri.

Remaja korban bully dituntut untukmengontrol emosinnya, sehingga bisaberinteraksi dengan orang lain dan menghadapi masalah yang dihadapinya. Dan disitu remaja juga diharapkan untuk tidak terpengaruh oleh emosi negatif, selain itu korban bullying juga mampu memotivasi dan memodifikasi emosinya yaitu kemampuan yang membuat individu mampu bertahan dalam masalah yang sedang dihadapinya. Jika remaja tidak bisa mengendalikan emosi maka remaja cenderung akan selalu memikirkan apapun yang menimpanya dan berampak pada psikologis kemudian bisa terjadi gangguan jiwa. Rina Mulyani (2014) menyatakan remaja yang telah menjadi korban bully harusmemiliki resiliensi yang bagus supaya remaja mampu bertahan dari keterpurukan, mampu bangkit dari kondisinya, mampu menentang tindakan bullying. Remaja yang menjadi korban bullying bisa menceritakan masalahnya kepada orang lain atau orang tua, karena orangtua sebagai lingkungan terdekat dan sebagai support system, abaikan penindas dan jauhi apabila korban tidak mengabaikan makan penindas akan merasa senang jika mendapatkan reaksi yang diinginkan, tingkatkan keberanian dan rasa percaya diri tunjukan kepada sekitar bahwa anda bukan orang yang lemah dan mudah untuk ditindas, beranikan bicara pada pelaku tunjukan bahwa apa yang dilakukan pelaku bukanlah hal yang baik bahkan berbahaya, bantu teman yang menjadi korban jika menyaksikan perilaku bully, jangan diam saja coba beri dukungan pada korban dan laporkan tindakan tersebut pada guru sekolah.

Remaja korban bully jika bisa menjauhi sumber stresor, remaja bisa meningkatkan keberanian dan meningkatkan rasa percaya diri menganggap dirinya mampu agar tidak menjadi korban bullying lagi. Dengan cara memperkuat dirinya, lebih mendekatkan diri kepada Tuhannya, mencoba untuk memodifikasi emosi seperti contoh membentuk diri sendiri untuk menjadi hal hal yang diinginkan, bersikap sabar dan tabah, memiliki pandangan yang positif kepada diri sendiri dan orang lain, peka terhadap perasaan orang lain, mampu intropeksi diri. Berdasarkan latar belakang diatas peneliti tertarik untuk melakukan penelitian tentang "Gambaran regulasi emosi remaja SMK korban bullying di SMK Multimedia Tumpang"

\section{METODE}

Desain dalam penelitian ini adalah deskriptif kuantitatif. Populasi penelitian ini adalah remaja SMK korban bullying. Sampel dalam penelitian ini adalah remaja SMK korban bullying dengan metode total sampling. Jumlah sampel dalam penelitian ini adalah 35 responden. 
HASIL

Tabel 1. Karakteristik Responden

\begin{tabular}{|c|c|c|}
\hline Keterangan & $f$ & $\%$ \\
\hline \multicolumn{3}{|l|}{ Usia } \\
\hline $12-15$ tahun & 0 & 0 \\
\hline $15-18$ tahun & 35 & 100 \\
\hline Jenis Kelamin & & \\
\hline Laki $\quad-\quad$ laki & 9 & 25,7 \\
\hline Perempuan & 26 & 74,3 \\
\hline $\begin{array}{l}\text { Pengalaman } \\
\text { sebelumnya }\end{array}$ & & \\
\hline $\mathrm{Ya}$ & 35 & 100 \\
\hline Tidak & 0 & 0 \\
\hline $\begin{array}{l}\text { Jenis bullying yang pernah } \\
\text { di alami }\end{array}$ & & \\
\hline Verbal & 30 & 85,7 \\
\hline Non Verbal & 5 & 14,3 \\
\hline Orang Terdekat Orang & & \\
\hline & 29 & 82,9 \\
\hline Teman & 5 & 14,3 \\
\hline Pacar & 1 & 2,8 \\
\hline $\begin{array}{l}\text { Pengalaman Trauma } \\
\text { Psikis }\end{array}$ & 22 & 62,9 \\
\hline Fisik & 13 & 37,1 \\
\hline $\begin{array}{l}\text { Kesulitan mengontrol emosi } \\
\text { Saat Pubertas }\end{array}$ & & \\
\hline $\mathrm{Ya}$ & 29 & 82,9 \\
\hline Tidak & 6 & 17,1 \\
\hline Total & 35 & 100 \\
\hline
\end{tabular}

Note: Descriptive kuantitative

Tabel diatas menunjukan bahwa pada regulasi emosi remaja SMK korban bullying terbanyak (23 remaja atau 65,7\%) yang mengalami regulasi emosi rendah.

Tabel 2. Karakteristik Berdasarkan Regulasi Emosi Remaja SMK Korban Bullying di SMK Multimedia Tumpang.

\begin{tabular}{cccc}
\hline No & Regulasi Emosi & $\mathbf{f}$ & $\%$ \\
\hline 1. & Tinggi & 5 & 14,3 \\
2. & Sedang & 7 & 20 \\
3. & Rendah & 23 & 65,7 \\
\hline & Total & 35 & 100
\end{tabular}

Note: Descriptive kuantitative

\section{PEMBAHASAN}

Hasil penelitian yang dilaksanakan pada 24 - 25 Februari 2021 dengan jumlah responden 35 remaja, diperoleh data bahwa sebagian besar remaja mengalami regulasi emosi rendah sebanyak (23 responden $65,7 \%$ ), sebagian kecil remaja mengalami regulasi emosi sedang (7 responden20\%), sebagian kecil remaja mengalami regulasi emosi tinggi (5 responden $14,3 \%$ ). Data menunjukkan hasil bahwa sebagian besar remaja memiliki regulasi emosi yang rendah. Hal ini bisa disebabkan karena usia, jenis kelamin, pengalaman bullying, jenis bullying, pengalaman trauma dan kesulitanmengontrol emosi saat pubertas. Regulasi emosi remaja sebagian besar remaja rendah bisa disebabkan pengalaman bullying 
sebelumnya.

Data umum penelitian menunjukkan bahwa sebagian besar (23 remaja 65,7\%) mempunyai pengalaman bullying sebelumnya (table 4.3). Pengalaman seseorang sebelumnya akan mempengaruhi pandanganseseorang tentang suatu hal serta bagaiamana mereka menyingkapi suatu persoalan, ketika sesorang memiliki pengalaman yang buruk sebelumnya maka ketika dihadapkan pada permasalahn yang sama maka emosi orang tersebut ikut terpengaruh. Hedrikson, 2013 mengatakan bahwa individu mempunyai pengalaman yang berbeda-beda dimana hal tersebutdapat mempengaruhi seseorang dalam mengatur emosinya, sehingga individu dapat banyak belajar dari orang lain dan sekitarnya tentang pengalaman bagaimana mengatur emosinya. Yang dapat mempengaruhi regulasi emosi remaja adalah ketika remaja mempunyai pengalaman bullying sebelumnya remaja dituntut untuk dapat mengatur dan mengontol emosinya serta remaja dapat memotivasi dan memodifikasi emosinya, sehingga remaja bisa mengontrol emosinya dan menghadapi masalahnya.

Jenis bullying yang diterima remaja juga bisa menyebabkan kemampuan regaulasi emosi remaja yang rendah. Yaitu berdasarkan data umum pada tabel 4.1, hampir seluruh (30 remaja atau 85,7\%) mengalami regulasi emosi rendah. Sedangkan berdasarkan data silang pada tabel 4.3, sebagian besar (19 remaja atau 63,3\%) mengalami jenis bullying verbal. Menurut Beane, (2014) bullying verbal juga dapat mempengaruhi regulasi emosi, karena mengacu pada perilaku - perilaku yangmelibatkan kontak langsung antara perilaku dan korban, seperti menghina, menyinggung, dan mengejek dengan sebutan nama orang tua, sehingga akan menimbulkan kesulitannya remaja ntuk mengontrol emosinya. Menurut peneliti jenis bullying sangat mempengaruhi regulasi emosi remaja. Seseorang ketika mengalami bullying verbal maka akan selalu diingat dalam pikirannya dan perasaanya. Bullying verbal yang diterima oleh remaja menimbulkan tekanan tersendiri pada psikis remaja, remaja menjaditerluka dan trauma sehingga remaja sulit untuk mengontrol emosinya dan ketika dihadapkan pada suatu masalah remaja akan marah dan emosi remaja tidak terkendali.

Ketiga yang mempengaruhi regulasi emosi remaja korban bullying adalah faktor pengalaman trauma. Berdasarkan data umum 4.1, sebagian besar (22 remaja atau 62,9\%) mengalami regulasi emosi rendah. Sedangkan berdasarkan data silang pada tabel 4.3, sebagian besar (15 remaja atau 68,1\%) mengalami pengalaman trauma psikis (pikiran sepertikeluaraga broken home, kehilangan, dan putus cinta). Menurut Hendrikson, (2013) faktor pengalaman trauma merupakan peristiwa yang pernah terjadi di masa lalu, terutama peristiwa yang dapat menanamkan rasa takut dan trauma serta waspada yang berlebihan dan dapat mempengaruhi kemampuan seseorang dalam mengatur emosinya. Menurut peneliti faktor pengalaman trauma remaja dapat mempengaruhi kodisi psikologis remaja dalam mengatur emosi remaja dan remaja akan mengingat kejadian - kejadian dulu yang pernah dialamisehingga remaja sulit untuk mengontrolemosinya.

Dari hasil penelitian berdasarkan tabel frekuensi diatas menunjukan seluruhnya (35 remaja atau 100\%) berusia 15 - 18 tahun. Sebagian besar (26 remaja atau 74,3\%) remaja berjenis kelamin perempuan. Seluruhnya (35 remaja atau 100\%) mengalami pengalaman bullying sebelumnya. Hampir seluruhnya (30 remaja atau $85,7 \%$ ) remaja mengalami jenis bullying verbal yaitu dengan menyinggung, mengejek, dan menyebut sebutandengan nama orang tua. Hampir seluruhnya (29 remaja atau 82,9 ) remaja orang terdekat yaitu orang tua. Sebagian besar (22 reamaja atau 62,9\%) mempunyai pengalaman trauma. Hampir seluruhnya (29 remaja atau $82,9 \%$ ) mengalami kesulitan mengontrol emosi setelah pubertas. Hal ini menunjukan regulasi emosi yang dialami remaja korban bullying dengan kategori regulasi emosi rendah adalah mereka dihadapkan banyak pengalaman yang kurang menyengkan. Menurut Sarwono, (2016). Pada usia 15 - 18 tahun remaja memasuki masa transisi dari anak - anakmenuju dewasa sehingga remaja dihadapkan dengan perubahan perubahan psikologis dan sosial emosional yang menyebabkan remaja sulit untuk mengontrol emosinya. 


\section{KESIMPULAN}

Dari penelitian tentang gambaran regulasi emosi remaja SMK korban bullying diSMK Multimedia Tumpang didapatkan sebagian besar remaja mengalami regulasiemosi dengan kategori rendah yaitu sebanyak (23 responden $65,7 \%$ ), sebagiankecil mengalami regulasi emosi sedang sebanyak (7 responden $20 \%$ ), dan sebagian kecil mengalami regulasi emosi tinggi sebanyak (5 responden 14,3\%). Banyaknya responden yang mengalami regulasi emosi rendah, hal ini dipengaruhi oleh usia, jenis kelamin, pengalam bullying sebelumnya, jenis bullying, pengalaman trauma, kesulitan mengontrol emosi setelah pubertas.

\section{DAFTAR PUSTAKA}

Aminah, Siti. (2015). Pengaruh PartisipasiSiswa Dalam Organisasi Terhadap Keterampilan Sosial (Social Skill) SMK Negeri Kota Yogyakarta Kelompok Pariwisata. Universitas Negeri Yogyakarta.

Ari Kunto. (2012). Prosedur Penelitian: Suatu Pendekatan Praktek. Jakarta:Rineka Cipta.

Akbar, G. (2013). Mental Imagery Mengenai Lingkungan Sosial Yang Baru Pada Korban Bullying, Jurnal Psikologi Unmul. Vol.1 No.1 Hal.23- 37.

Christina, V. (2011). Dampak Psikologis Pada Remaja Korban Bullying. Program Sarjana UniversitasKatolik Soegijapranata. Semarang.

Diah Wahyuningsih. (2016). Bullying Ditinjau dari Secure Attachment Dengan Oran Tua dan Kontrol Diri Pada Siswa SMA Negeri 8 Surakarta. Skripsi. Program Studi Psikologi Fakultas Kedokteran Universitas Sebelas Maret.

Desmita. (2010). Pengaruh Penyuluhan Terhadap Tingkat Pengetahuan Kesehatan Reproduksi Pada Remaja Siswa SMP Kristen Gergaji. Karya Tulis IImiah. Program Sarjana Kedokteran Universitas Diponegoro. Semarang

Dogruer. (2015). Penindas, Tertindas, dan Penonton. Resep Memutus Rantai Kekerasan Anak Dari Prasekolah Hingga SMU. Jakarta: Serambi.

Donsu. (2017). Psikologi Keperawatan.

Yogyakarta: Pustaka Baru Press.

Fera Feriyal. (2014). Perilaku Bullying Ditinjau Dari Regulasi Emosi Dan SelfEsteeem Pada Siswa Kelas XI Jurusan Otomotif STM YudyaKarya Magelang. Skripsi. Program Studi Psikologi FakultasKedokteran Universitas Sebelas Maret.

Gross, James J. (2014). Handbook of Emotional Regulation, Second Edition. New York: The Guilford Press.

Hurlock dan Sarwono. (2016). Psikologi Perkembangan. Erlangga: Jakarta.

Konoka dan Johja. (2011:240). Remajadan masalahnya. Bandung:Alfabeta.

King, L.A. (2010). Psikologi Umum sebuah Pandangan Apresiatif The Science of Psychology: (An Appreciative View). Buku 1. Jakarta

: Salemba Humanika.

Muhammad Asrori. (2010). Faktor faktor yang memoengaruhi perkembangan remaja. Jakarta: Erlangga.

Nasirotun. (2013). PerkembanganPengetahuan. Jakarta: Salemba

Notoadmodjo. (2018). Metodologi Penelitian IImu Kesehatan. Jakarta Selatan: Rineka Cipta.

Nursalam. (2016). Metodologi Penelitian IImu Keperawatan. Jakarta Selatan: Salemba Medika. 
Oktaviana. (2015). Jurnal IImiah IImuPsikologi. Surakarta

Papalia dan Olds. (2010). PerkembanganManusia. Jakarta:SalembaHumanika.

Parzefal, M-R., \& Salin, D. M. (2010). Peception of and reactions to workplace bullying: A social exchangeperpective. Human Relations, 63(6), 761-780.

Rina Mulyani, (2014). Pendekatankonseling spiritual untuk mengatasi bullying (kekerasan) Siswa SMANegri 1 Depok Seleman Yogyakarta.

Ratnasari. S., \& Suleeman. J. (2017). Perbedaan Regulasi EmosiPerempuan dan Laki-laki di Perguruan Tinggi. Jurnal PsikologiSosial. 15 (01) 35-46.

Sugiyono. (2016). Metode Penelitian Kuantitatif, Kualitatif, dan $R \& D$. Bandung:PT.Alfabet

Skiner. (2018). Dalam Notoatmodjo (2011). Bentuk Respon Terhadap Stimulus. Jurnal Psikologi.

Wati, P. (2012). Hubungan Bullying dan Keterampilan Sosial Di Sekolah Dasar. Jurnal Psikologi.

Wawan \& M Dewi. (2011). Teori dan Pengukuran Pengetahuan, Sikap, dan Perilaku Manusia.cetakan II.Yogyakarta: Nuha Medika.

Zakiyah, EZ., dkk. (2017). Faktor yang mempengaruhi remaja dalam melakukan bullying. Jurnal Penelitian \& PPM 4 (2):129-389.

KPAI, (2018). Kasus Bullying di Sekolah. Jakarta pusat: https://amp.kompas.com/nasional/read/2019/07/23/18331981/hari-anak-nasional-kpaiingatkan-masyarakat-jangan-anggap-remeh-kasus. 